\title{
Therapeutic effects of Lactobacillus casei Qian treatment in activated carbon-induced constipated mice
}

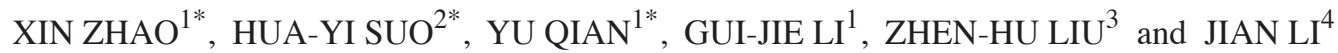 \\ ${ }^{1}$ Department of Biological and Chemical Engineering, Chongqing University of Education, Chongqing 400067; \\ ${ }^{2}$ College of Food Science, Southwest University, Chongqing 400715; ${ }^{3}$ Science and Technology Administration, \\ Chinese Academy of Agricultural Sciences, Beijing 100081; ${ }^{4}$ Institute of Qinghai-Tibetan Plateau, \\ Southwest University for Nationalities, Chengdu, Sichuan 610041, P.R. China
}

Received May 23, 2014; Accepted April 10, 2015

DOI: $10.3892 / \mathrm{mmr} .2015 .3737$

\begin{abstract}
In the present study, the therapeutic effects of Lactobacillus casei Qian (LC-Qian), the key microorganism in Tibetan yak yoghurt, on activated carbon-induced constipation were determined in vivo. ICR mice were treated with LC-Qian for nine days by oral administration. The body weight, defecation status, gastrointestinal transit and defecation time of mice were assessed, and the serum levels of motilin (MTL), gastrin (Gas), endothelin (ET), somatostatin (SS), acetylcholinesterase (AChE), substance P (SP) and vasoactive intestinal peptide (VIP) were further evaluated. Bisacodyl was used as the positive control. The time until the first black stool defecation following carbon intake of the normal, control, $100 \mathrm{mg} / \mathrm{kg}$ bisacodyl-treated, Lactobacillus bulgaricus (LB)-treated, LC-Qian (L)- and LC-Qian (H)-treated mice was 93, 231, 121, 194, 172 and 157 min, respectively. Following treatment with LC-Qian, the gastrointestinal transit was increased to 52.4\% [LC-Qian (L)] and 65.8\% [LC-Qian (H)], while that in the group treated with the common lactic acid bacteria of LB was $40.3 \%$. The MTL, Gas, ET, AChE, SP and VIP serum levels were significantly increased and levels of SS were reduced in mice following LC-Qian treatment compared with those in the control mice $(\mathrm{P}<0.05)$. Reverse transcription quantitative polymerase chain reaction indicated that LC-Qian raised the c-Kit, GDNF as well as SCF mRNA expression levels and reduced the TRPV1 and NOS expression levels in tissue of the small intestine in mice. These results suggested that lactic acid bacteria prevent constipation in mice, among which LC-Qian was the most effective.
\end{abstract}

Correspondence to: Professor Jian Li, Institute of Qinghai-Tibetan Plateau, Southwest University for Nationalities, 16 Yihuan Road, Chengdu, Sichuan 610041, P.R. China

E-mail: lijian@swun.cn

*Contributed equally

Key words: Lactobacillus casei Qian, activated carbon, constipation, bisacodyl, gastrointestinal transit

\section{Introduction}

Yak yogurt is a traditional fermented dairy product from the Chinese Tibetan area, which has various functions, including aiding digestion and increasing appetite (1). According to a previous study, yak yogurt has the ability to lower cholesterol and prevent cardiovascular and cerebrovascular diseases (2). Previously, the key microorganism was separated from yak yoghurt from the Tibetan area, and the lactic acid bacteria was named Lactobacillus casei Qian (LC-Qian) following identification.

Constipation is a common cause of physical discomfort, and is associated with reduced bowel movements, difficulty in passing stools and dry feces (3). Previous studies have used animals with constipation induced by activated carbon in order to investigate the activities of drugs for constipation treatment $(4,5)$. When activated carbon enters the intestines, it attaches to the mucosal surface of the gastrointestinal tract, reduces gastrointestinal fluid and weakens gastrointestinal peristalsis, which leads to constipation. These conditions leading to constipation tend to occur in women, and therefore, studies have used activated carbon to induce constipation in female experimental mice. Farrugia et al (6) reported that large quantities of activated carbon were able to obstruct the digestive tract. The present study aimed to determine the constipation-preventing activity of LC-Qian using a mouse model of activated carbon-induced constipation. Gastrointestinal (GI) transit, time of the first black stool defecation following carbon intake, histopathological features, serum levels of motilin (MTL), gastrin (Gas), endothelin (ET), somatostatin (SS), acetylcholinesterase (AChE), substance P (SP) and vasoactive intestinal peptide (VIP), as well as mRNA expression levels of c-Kit, TRPV1, GDNF, NOS and SCF were determined in the present study. Bisacodyl is a laxative drug, which acts directly on the colon to aid intestinal peristalsis and bowel movements (7). Therefore, bisacodyl is used for relief from constipation and neurogenic bowel dysfunction, and is used to prepare the bowel prior to medical examinations. Thus, bisacodyl was selected for use as a positive control in the animal experiments (8-10).

The present study compared the anti-constipative effects of LC-Qian with those of Lactobacillus bulgaricus (LB) as a reference, which is present in common yoghurt. By comparing the 
cholate tolerance and hydrophobic properties of LC-Qian and LB, the ability of LC-Qian to pass through the stomach and guts and to adhere to the small intestine was explained. The present study reported a curative effect of LC-Qian on constipation, therefore aiding in the development of therapeutically effective lactic acid bacteria.

\section{Materials and methods}

Microorganism strains. LC-Qian was separated from yak yoghurt from Hongyuan county (Ngawa Prefecture, Sichuan Province, China) and was preserved at the China Center for Type Culture Collection (M2013514; Wuhan, Hubei, China). LB was purchased from the Institute of Microbiology of the Chinese Academy of Sciences (Beijing, China).

Endurance capacity of lactic acid bacteria. To produce artificial gastric juice, $\mathrm{NaCl}$ (0.2\%; Tianjin Dingshengxin Chemical Co., Ltd., Tianjin, China) and pepsin (0.35\%; Tianjin Dingshengxin Chemical Co., Ltd.) were added to distilled water and the solution was adjusted to $\mathrm{pH} 3.0$ using $\mathrm{HCl}$. Various concentrations of lactic acid bacteria culture $(1 \mathrm{ml})$ were mixed with $\mathrm{pH}-3.0$ artificial gastric juice $(9 \mathrm{ml})$ and the mixture was incubated in a thermostatic oscillator (SHA-C; Shanghai Gaoxing Equipment Co., Ltd., Shanghai, China) for $3 \mathrm{~h}\left(300 \mathrm{x} \mathrm{g} ; 37^{\circ} \mathrm{C}\right)$. A total of $200 \mu \mathrm{l}$ incubated mixture was then added to an MRS agar plate (Hangzhou Baisi Biotechnology Co., Ltd., Hangzhou, Zhejiang, China) and incubated at $37^{\circ} \mathrm{C}$ for $48 \mathrm{~h}$. The colony-forming units (CFUs) were then counted and the survival rate was calculated (11).

Lactic acid bacterial tolerance of bile salt (oxgal). The $2 \%$ lactic acid bacteria culture was added into MRS-thio (MRS plus $0.2 \%$ sodium thioglycolate), and different concentrations of oxgall $(0,0.3,0.5$ and $1.0 \%$; Beijing Aoboxing Bio-tech Co., Ltd., Beijing, China) were added to the solution. The the mixture was then incubated at $37^{\circ} \mathrm{C}$ for $24 \mathrm{~h}$ and its optical density value was determined (11).

Hydrophobic properties of lactic acid bacteria. The lactic acid bacteria culture liquid $(5 \mathrm{ml})$ was centrifuged at $3,000 \times \mathrm{g}$ for $10 \mathrm{~min}$. The supernatant was discarded and $5 \mathrm{ml}$ phosphate-buffered saline (PBS; $50 \mathrm{mM}, \mathrm{pH} 6.5$; Beijing Solarbio Co., Ltd., Beijing, China) was added into the tube to suspend the lactic acid bacteria. The suspension was then centrifuged twice at 3,000 x g for $10 \mathrm{~min}$. The lactic acid bacteria were re-suspended in $8 \mathrm{ml}$ dimethylbenzene (Liaoning Jiacheng Fine Chemicals Co., Ltd., Shenyang, Liaoning, China) and $4 \mathrm{ml} \mathrm{PBS}$, and the absorbance of the aqueous layer was measured at $560 \mathrm{~nm}$ (12).

Induction of constipation in mice. The 120 female ICR mice (seven-week-old) were maintained in a temperature controlled facility (temperature, $25 \pm 2{ }^{\circ} \mathrm{C}$; relative humidity $50 \pm 5 \%$ ) with a $12 \mathrm{~h}$ light/dark cycle and free access to water and a standard mouse diet. The mice were randomly divided into the following six groups: Normal, control, bisacodyl, LB, LC-Qian (L) and LC-Qian (H). The normal group received a normal diet and water for 9 days, while the control group received a normal diet and water for 9 days as well as oral
Table I. Sequences of reverse transcription polymerase chain reaction primers used.

\begin{tabular}{ll}
\hline Gene name & \multicolumn{1}{c}{ Sequence } \\
\hline c-Kit & F: 5'-AGA CCG AAC GCA ACT T-3' \\
& R: 5'-GGT GCC ATC CAC TTC A-3' \\
SCF & F: 5'-AAA CTG GTG GCG AAT C-3' \\
& R: 5'-CAC GGG TAG CAA GAA C-3' \\
TRPV1 & F: 5'-AGC GAG TTC AAA GAC CCA GA-3' \\
& R: 5'-TTC TCC ACC AAG AGG GTC AC-3' \\
GDNF & F: 5'-TTT TAT TCA AGC CAC CAT C-3' \\
& R: 5'-AGC CCA AAC CCA AGT CA-3' \\
NOS & F: 5'-CCA CAT CTG GCA GGA TGA GAA-3' \\
& R: 5'-AGG CAC AGAACT GAG GGT ACA-3' \\
GAPDH & F: 5'-CGG AGT CAA CGG ATT TGG TC-3' \\
& R: 5'-AGC CTT CTC CAT GGT CGT GA-3' \\
\hline
\end{tabular}

F, forward; R, reverse.

administration of activated carbon $(0.2 \mathrm{ml} 10 \%$ activated carbon, w/w; dissolved in 10\% arabic gum; Tianjin Damao Chemical Reagent Factory, Tianjin, China) from the sixth to ninth day at 6 p.m. The bisacodyl group was treated with $100 \mathrm{mg} / \mathrm{kg}$ dose bisacodyl by oral administration for 9 days and activated carbon (as in the control group). Furthermore, the LB group was fed $1 \times 10^{9} \mathrm{CFU} / \mathrm{ml} \mathrm{LB}$ suspension $(2 \mathrm{ml})$ and activated carbon. Finally, the LC-Qian (L) group was fed $1 \times 10^{8} \mathrm{CFU} / \mathrm{ml}$ LC-Qian suspension $(2 \mathrm{ml})$ and activated carbon, and the LC-Qian $(\mathrm{H})$ group was fed $1 \times 10^{9} \mathrm{CFU} / \mathrm{ml}$ LC-Qian suspension $(2 \mathrm{ml})$ and activated carbon (13). The experiments were performed following a protocol approved by the Animal Ethics Committee of Chongqing Medical University (Chongqing, China). The body weight, stool weight, number and moisture levels were determined at 9 a.m.

GI transit and defecation time. The experimental mice were fasted (with access to water) from the ninth day at 6 p.m. for $16 \mathrm{~h}$, then all groups of mice received activated carbon by oral administration. After $30 \mathrm{~min}$, all mice were sacrificed by cervical dislocation and the small intestines, from the pylorus to the cecum, were collected. The GI transits of mice were determined as the percentage of the distance traveled by the activated carbon meal relative to the total length of the small intestine. The following equation was used to calculate GI transit: GI transit $(\%)=$ distance traveled by the activated carbon/total length of the small intestine $\mathrm{x} 100$.

MTL, Gas, ET, SS, AChE, SP and VIP levels in the serum. MTL, Gas, ET, SS, AChE, SP and VIP serum levels were measured using the following radioimmunoassay kits: Motilin Elisa kit, gastrin Elisa kit, endothelin Elisa kit, somatostatin Elisa kit, acetylcholinesterase Elisa kit, substance P Elisa kit and vasoactive intestinal peptide Elisa kit (Beijing Puer Weiye Biotechnology Co., Ltd., Beijing, China) following the manufacturer's instructions. 
Table II. Survival in pH 3.0 artificial gastric juice ${ }^{\text {a }}$, hydrophobic properties and growth in bile salt of LC-Qian.

\begin{tabular}{|c|c|c|c|c|c|}
\hline \multirow[b]{2}{*}{ Strain } & \multirow{2}{*}{$\begin{array}{l}\text { Survival in } \mathrm{pH} 3.0 \\
\text { artificial gastric juice }(\%)\end{array}$} & \multirow{2}{*}{$\begin{array}{c}\text { Hydrophobic } \\
\text { properties }^{\mathrm{b}}(\%)\end{array}$} & \multicolumn{3}{|c|}{ Growth in bile salt ${ }^{\mathrm{c}}(\%)$} \\
\hline & & & $0.3 \%$ & $0.5 \%$ & $1.0 \%$ \\
\hline LC-Qian & $62.51 \pm 7.35^{\mathrm{d}}$ & $51.30 \pm 4.28^{\mathrm{d}}$ & $11.32 \pm 1.48^{\mathrm{d}}$ & $9.28 \pm 1.25^{\mathrm{d}}$ & $7.86 \pm 0.45^{\mathrm{d}}$ \\
\hline $\mathrm{LB}$ & $26.33 \pm 2.73^{\mathrm{e}}$ & $24.89 \pm 2.32^{\mathrm{e}}$ & $2.57 \pm 0.30^{\mathrm{e}}$ & $1.52 \pm 0.22^{\mathrm{e}}$ & $1.26 \pm 0.25^{\mathrm{e}}$ \\
\hline
\end{tabular}

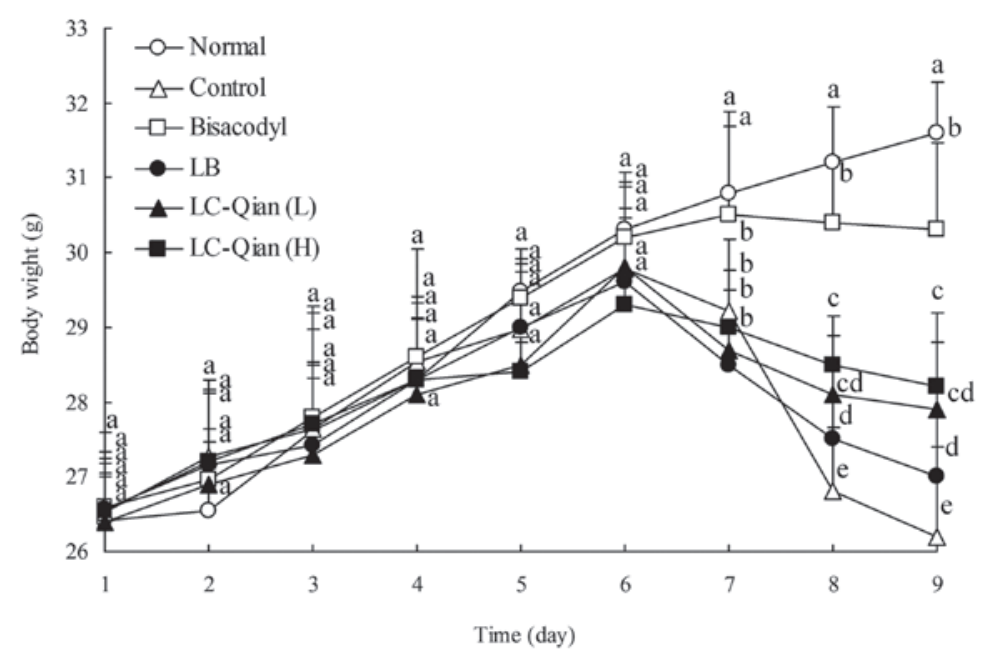

Figure 1. Alterations in the body weight of experimental mice. Values are expressed as the mean \pm standard deviation ( $\mathrm{n}=10$ ICR mice in each group). Bisacodyl, $100 \mathrm{mg} / \mathrm{kg}$ body weight; LB, $1.0 \times 10^{9} \mathrm{CFU} / \mathrm{kg}$ body weight; LC-Qian (L), 1.0x10 ${ }^{8} \mathrm{CFU} / \mathrm{kg}$ body weight, LC-Qian (H), $1.0 \times 10^{9} \mathrm{CFU} / \mathrm{kg}$ body weight. ${ }^{\mathrm{a}-\mathrm{e}}$ Mean values with different letters are significantly difference $(\mathrm{P}<0.05)$, according to Duncan's multiple range test. LB, Lactobacillus bulgaricus; LC-Qian, Lactobacillus casei Qian; CFU, colony-forming unit.

Reverse transcription polymerase chain reaction $(R T-q P C R)$. Total RNA was isolated using TRIzol reagent (Invitrogen Life Technologies, Carlsbad, CA, USA) according to the manufacturer's instructions and the concentration was determined using a ultraviolet spectrophotometer. The RNAs were centrifuged at $12,000 \mathrm{x} \mathrm{g}$ for $15 \mathrm{~min}$ at $25^{\circ} \mathrm{C}$ following the addition of chloroform. Isopropanol (Liaoning Jiacheng Fine Chemicals Co., Ltd., Shenyang, Liaoning, China) was added to the supernatant at a 1:1 ratio and the RNA was pelleted by centrifugation $(12,000 \mathrm{x} \mathrm{g}$ for $15 \mathrm{~min}$ at $4^{\circ} \mathrm{C}$ ). Subsequent to washing with ethanol (Liaoning Jiacheng Fine Chemicals Co., Ltd.), the RNA was solubilized in diethyl pyrocarbonate (Sigma-Aldrich, St. Louis, MO, USA)-treated RNase-free water and quantified by measuring the absorbance at $260 \mathrm{~nm}$ using a UV-1750 spectrophotometer (Shimadzu Corporation, Kyoto, Japan). Equal amounts of RNA $(1 \mu \mathrm{g})$ were reverse transcribed in a master mix containing $1 \mathrm{X}$ reverse transcriptase buffer (Sigma-Aldrich), desoxyribonucleotidyl triphosphates (1 mM; Sigma-Aldrich), oligodT18 primers (500 ng; Shanghai Haling Biological Technology Co., Ltd., Shanghai, China), Moloney murine leukemia virus reverse transcriptase (140 U; Promega Corporation, Madison, WI, USA) and RNase inhibitor (40 U; Promega Corporation) for $45 \mathrm{~min}$ at $42^{\circ} \mathrm{C}$. PCR was then performed in an automatic thermocycler
(Applied Biosystems, Life Technologies, Fisher Thermo Scientific, Waltham, MA, USA) at $94^{\circ} \mathrm{C}$ denaturation for $1 \mathrm{~min}$, annealing at $56^{\circ} \mathrm{C}$ for $1 \mathrm{~min}$ and 30 cycles of $72^{\circ} \mathrm{C}$ for $1 \mathrm{~min}$. The sequences of primers are presented in Table I and the PCR products were separated in 2\% agarose gels (Thermo Fisher Scientific, Waltham, MA, USA) and visualized by ethidium bromide (Beijing Dingguo Changsheng Biotechnology Co., Ltd., Beijing, China) staining. Gene expression was quantified using ImageJ software version 1.44 (National Institutes of Health, Bethesda, MD, USA) (14).

Statistical analysis. Values are expressed as the mean \pm standard deviation. Differences between the mean values for each group were analyzed by one-way analysis of variance using Duncan's multiple range test and $\mathrm{P}<0.05$ was considered to indicate a statistically significant difference. SAS, version 9.2 (SAS Institute Inc., Cary, NC, USA) was used for statistical analyses.

\section{Results}

LC-Qian exhibits improved abilities to overcome biological barriers and has increased hydrophobicity compared with $L B$. Gastrointestinal survival abilities of LC-Qian were 
Table III. Fecal properties of mice during the experiment.

LC-Qian (x109 CFU/kg body weight)

Treatment

Normal

Control

Bisacodyl

LB

0.5

1.0

Day 1-6 (dose with samples)

Defecation weight $(\mathrm{g})$

Particle counts of feces (n)

Water content of feces (\%)

$\begin{array}{ccc}0.91 \pm 0.06^{\mathrm{a}} & 0.92 \pm 0.12^{\mathrm{a}} & 1.04 \pm 0.06^{\mathrm{a}} \\ 36 \pm 5^{\mathrm{b}} & 36 \pm 2^{\mathrm{b}} & 44 \pm 4^{\mathrm{a}} \\ 46 \pm 5^{\mathrm{a}} & 47 \pm 7^{\mathrm{a}} & 52 \pm 6^{\mathrm{a}}\end{array}$

$0.91 \pm 0.07^{\mathrm{a}}$
$35 \pm 3^{\mathrm{b}}$
$47 \pm 5^{\mathrm{a}}$

$0.92 \pm 0.05^{\mathrm{a}}$
$35 \pm 3^{\mathrm{b}}$
$48 \pm 4^{\mathrm{a}}$

$0.91 \pm 0.04^{\mathrm{a}}$

Day 7-9 (High-concentration dose with samples and activated carbon)

\begin{tabular}{lcccccc} 
Defecation weight $(\mathrm{g})$ & $0.92 \pm 0.06^{\mathrm{a}}$ & $0.32 \pm 0.03^{\mathrm{e}}$ & $0.68 \pm 0.07^{\mathrm{b}}$ & $0.41 \pm 0.04^{\mathrm{d}}$ & $0.54 \pm 0.05^{\mathrm{c}}$ & $0.60 \pm 0.04^{\mathrm{b}}$ \\
Particle counts of feces (n) & $37 \pm 4^{\mathrm{a}}$ & $14 \pm 3^{\mathrm{d}}$ & $33 \pm 3^{\mathrm{ab}}$ & $20 \pm 4^{\mathrm{c}}$ & $23 \pm 3^{\mathrm{c}}$ & $28 \pm 5^{\mathrm{b}}$ \\
Water content of feces $(\%)$ & $45 \pm 4^{\mathrm{a}}$ & $14 \pm 2^{\mathrm{d}}$ & $38 \pm 4^{\mathrm{ab}}$ & $20 \pm 3^{\mathrm{c}}$ & $24 \pm 4^{\mathrm{c}}$ & $30 \pm 3^{\mathrm{b}}$ \\
\hline
\end{tabular}

${ }^{\mathrm{a}-\mathrm{e}}$ Mean values with different letters are significantly difference $(\mathrm{P}<0.05)$, according to Duncan's multiple range test Values are expressed as the mean \pm standard deviation ( $\mathrm{n}=10 \mathrm{ICR}$ mice/group). Bisacodyl, $100 \mathrm{mg} / \mathrm{kg}$ body weight; LB, $1.0 \times 10^{9} \mathrm{CFU} / \mathrm{kg}$ body weight. LB, Lactobacillus bulgaricus; LC-Qian, Lactobacillus casei Qian; CFU, colony-forming unit.

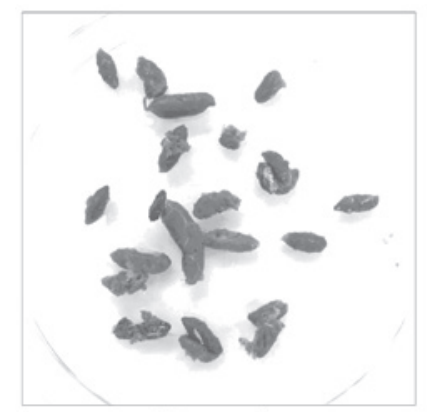

Normal

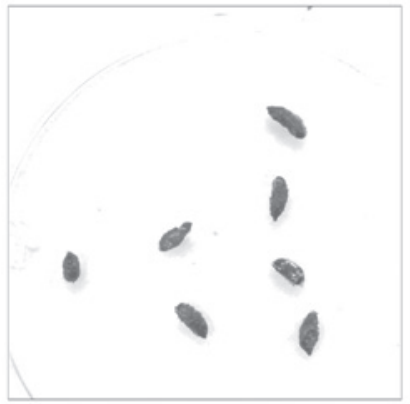

LB

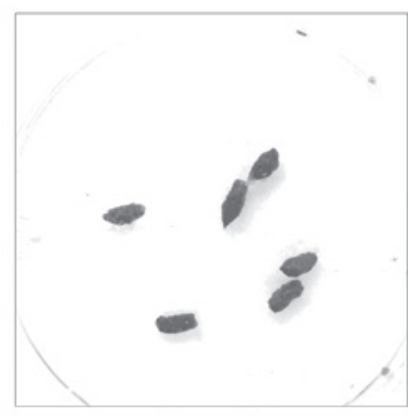

Control

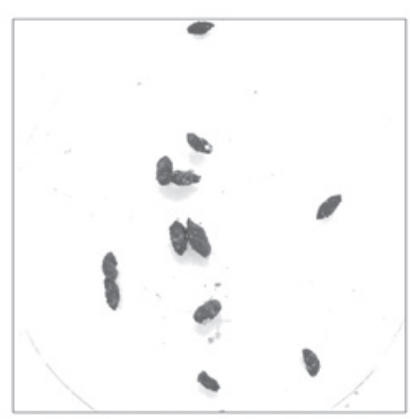

LC-Qian (L)

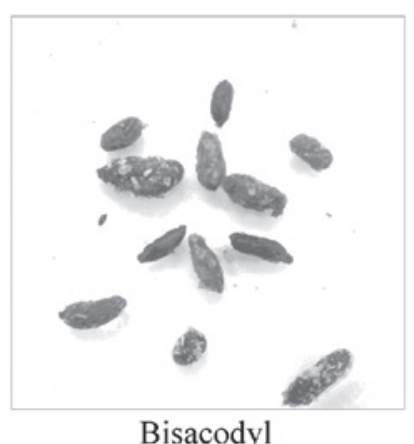

Bisacodyl

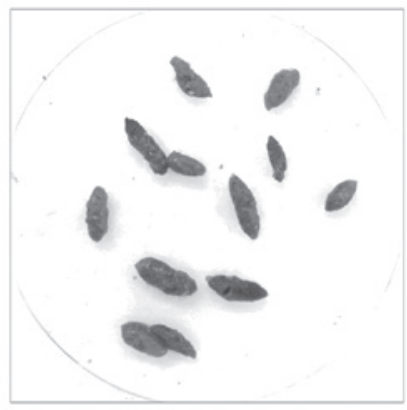

LC-Qian (H)

Figure 2. Fecal shapes in experimental mice. Bisacodyl, $100 \mathrm{mg} / \mathrm{kg}$ body weight; LB, $1.0 \times 10^{9} \mathrm{CFU} / \mathrm{kg}$ body weight; LC-Qian (L), $1.0 x 10^{8} \mathrm{CFU} / \mathrm{kg}$ body weight; LC-Qian (H), 1.0x10 ${ }^{9} \mathrm{CFU} / \mathrm{kg}$ body weight. LB, Lactobacillus bulgaricus; LC-Qian, Lactobacillus casei Qian; CFU, colony-forming unit.

determined using artificial gastric juice, bile salt and hydrophobic property tests. LC-Qian was observed to possess a significantly higher survival rate in gastric juice, greater hydrophobicity and enhanced growth in the presence of bile salt as compared with LB (Table II). In particular, in the experiment in which bacteria were growth in the presence of bile salts, the growth of LC-Qian was 7.8-11.3-fold greater than that of LB.

LC-Qian ameliorates weight reduction in mice with constipation. The body weight of mice in the normal group increased during the experiments (Fig. 1). The control mice also exhibited natural increases in body weight during to the first six days; however, after the sixth day, the body weight was significantly reduced $(\mathrm{P}<0.05)$. Following treatment with activated carbon, the body weights of the mice in the bisacodyl, LB and LC-Qian groups was also reduced; however, bisacodyl and LC-Qian were able to significantly ameliorate these reductions $(\mathrm{P}<0.05)$.

LC-Qian ameliorates fecal abnormalities in mice with constipation. In the first six days, the defecation weight, particle count of feces and water content of feces in the different groups were not significantly different (Table III). 


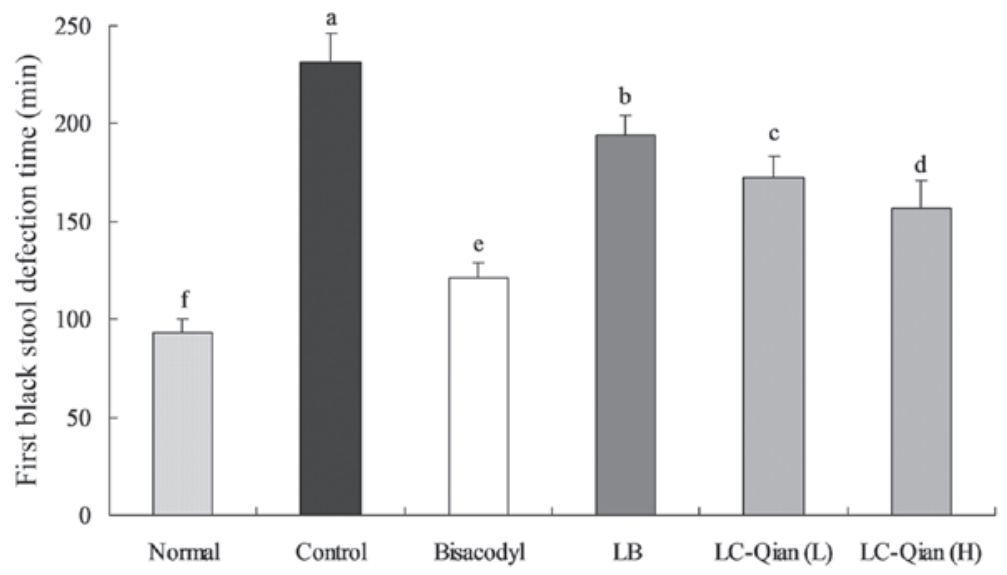

Figure 3. Time until the first black stool defecation of mice following the induction of constipation using activated carbon on the last day of the experiment. Values are expressed as the mean \pm standard deviation ( $\mathrm{n}=10 \mathrm{ICR}$ mice $/$ group). Bisacodyl, $100 \mathrm{mg} / \mathrm{kg}$ body weight; LB, $1.0 \times 10^{9} \mathrm{CFU} / \mathrm{kg}$ body weight; LC-Qian (L), 1.0x $10^{8} \mathrm{CFU} / \mathrm{kg}$ body weight; LC-Qian (H), 1.0x10 $\mathrm{CFU} / \mathrm{kg}$ body weight. ${ }^{\text {a-f }}$ Mean values with different letters over the bars are significantly different $(\mathrm{P}<0.05)$ according to Duncan's multiple range test. LB, Lactobacillus bulgaricus; LC-Qian, Lactobacillus casei Qian; CFU, colony-forming unit.
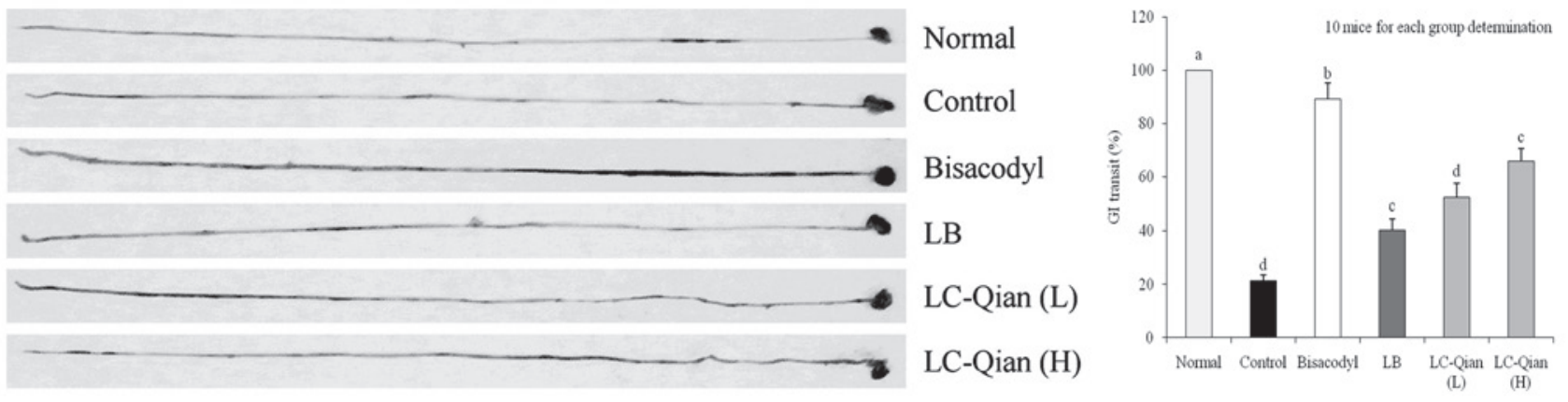

Figure 4. Gastrointestinal transit of mice following the induction of constipation using activated carbon on the last day in the experiment. Images are representative of 10 ICR mice in each group. Bisacodyl, $100 \mathrm{mg} / \mathrm{kg}$ body weight; LB, $1.0 x 10^{9} \mathrm{CFU} / \mathrm{kg}$ body weight; LC-Qian (L), $1.0 \times 10^{8} \mathrm{CFU} / \mathrm{kg}$ body weight; LC-Qian $(\mathrm{H}), 1.0 \times 10^{9} \mathrm{CFU} / \mathrm{kg}$ body weight. ${ }^{\mathrm{a}-\mathrm{e}}$ Mean values with different letters are significantly difference $(\mathrm{P}<0.05)$, according to Duncan's multiple range test. LB, Lactobacillus bulgaricus; LC-Qian, Lactobacillus casei Qian; CFU, colony-forming unit.

From the seventh day, however, the control mice exhibited the lowest defecation weight, particle counts of feces and water content of feces. LC-Qian was able to ameliorate these effects, with the high concentration of LC-Qian $\left(1.0 \times 10^{9}\right)$ being more effective than the low concentration (Table III, Fig. 2).

LC-Qian reduces carbon-induced increases in time until first black stool defecation. The time until the first black stool defecation of control mice following carbon intake was the longest at $231 \pm 15 \mathrm{~min}$, while it was shortest for the normal mice at $93 \pm 7$ min (Fig. 3). LB and LC-Qian (L) were able to reduce the time until the first defecation of black stool to $194 \pm 10$ and $172 \pm 11 \mathrm{~min}$, respectively. The LC-Qian (H) group exhibited a marked reduction of the time until the first black stool defecation, namely to $157 \pm 14 \mathrm{~min}$, which was similar to that of the bisacodyl group mice (121 $\pm 8 \mathrm{~min})$.

LC-Qian improves GI transit in constipated mice. The GI transit of control mice was lowest out of all groups at $21.3 \pm 2.2 \%$ of that of the normal group (Fig. 4). The lactic acid bacteria were able to increase the GI transit compared with that of control mice; LB, LC-Qian (L) and LC-Qian (H) increased
GI transit to $40.3 \pm 4.3,52.4 \pm 5.1$ and $65.8 \pm 4.8 \%$, respectively. LC-Qian (H) was observed to cause a marginally lower GI transit than bisacodyl $(89.2 \pm 6.0 \%)$.

LC-Qian partly restores MTL, Gas, ET, SS, AChE, SP and VIP levels in serum of constipated mice. Following treatment with activated carbon, the control mice exhibited the highest SS levels and lowest levels of MTL, Gas, ET, AChE, SP and VIP (Table IV). The normal mice exhibited opposite trends compared with those in the control mice. Bisacodyl- and LC-Qian-treated mice had greater MTL, Gas, ET, AChE, SP and VIP levels, and lower SS levels than the control mice $(\mathrm{P}<0.05)$. High concentrations of LC-Qian partly restored the levels of these substances to those of normal mice.

LC-Qian attenuates constipation-induced decreases in the gene expression of $c$-Kit and SCF. The c-Kit and SCF mRNA expression levels in small intestine tissue were measured using RT-qPCR. The expression levels of c-Kit and SCF in normal mice were the greatest, while the control mice exhibited the lowest expression levels (Fig. 5). LC-Qian, particularly at the high concentration, increased these expression levels compared with those in control mice $(\mathrm{P}<0.05)$. 
Table IV. Serum levels of MTL, Gas, ET, SS, AchE, SP and VIP in experimental mice (pg/ml).

LC-Qian

(x10 $\mathrm{CFU} / \mathrm{kg}$ body weight)

\begin{tabular}{lcrrrrr}
\cline { 5 - 6 } Substance & Normal & Control & Bisacodyl & LB & \multicolumn{1}{c}{0.5} & \multicolumn{1}{c}{1.0} \\
\hline MTL & $176.8 \pm 10.7^{\mathrm{a}}$ & $96.3 \pm 4.5^{\mathrm{f}}$ & $159.7 \pm 5.8^{\mathrm{b}}$ & $110.6 \pm .6 .2^{\mathrm{e}}$ & $128.6 \pm 7.2^{\mathrm{d}}$ & $139.2 \pm 7.5^{\mathrm{c}}$ \\
Gas & $88.9 \pm 3.9^{\mathrm{a}}$ & $40.1 \pm 2.5^{\mathrm{f}}$ & $70.6 \pm 2.1^{\mathrm{b}}$ & $48.2 \pm 2.0^{\mathrm{e}}$ & $57.1 \pm 2.6^{\mathrm{e}}$ & $65.5 \pm 2.3^{\mathrm{c}}$ \\
ET & $15.2 \pm 0.6^{\mathrm{a}}$ & $6.7 \pm 0.2^{\mathrm{f}}$ & $12.8 \pm 0.5^{\mathrm{b}}$ & $7.7 \pm 0.5^{\mathrm{e}}$ & $9.1 \pm 0.4^{\mathrm{d}}$ & $9.7 \pm 0.6^{\mathrm{c}}$ \\
SS & $35.6 \pm .2 .^{\mathrm{f}}$ & $64.1 \pm 3.1^{\mathrm{a}}$ & $42.4 \pm 2.2^{\mathrm{e}}$ & $57.1 \pm 2.5^{\mathrm{b}}$ & $52.1 \pm 1.2^{\mathrm{c}}$ & $46.8 \pm 2.6^{\mathrm{d}}$ \\
AchE & $35.2 \pm 2.4^{\mathrm{a}}$ & $11.3 \pm 1.8^{\mathrm{f}}$ & $30.1 \pm 2.1^{\mathrm{b}}$ & $16.2 \pm 1.7^{\mathrm{e}}$ & $18.7 \pm 1.2^{\mathrm{d}}$ & $22.5 \pm 0.9^{\mathrm{c}}$ \\
SP & $68.8 \pm 3.7^{\mathrm{a}}$ & $33.6 \pm 2.3^{\mathrm{f}}$ & $59.2 \pm 1.6^{\mathrm{b}}$ & $42.5 \pm 1.1^{\mathrm{e}}$ & $44.0 \pm 1.1^{\mathrm{d}}$ & $48.9 \pm 1.6^{\mathrm{c}}$ \\
VIP & $57.9 \pm 2.8^{\mathrm{a}}$ & $22.3 \pm 1.4^{\mathrm{f}}$ & $49.0 \pm 1.6^{\mathrm{b}}$ & $31.7 \pm 1.6^{\mathrm{e}}$ & $36.8 \pm 0.7^{\mathrm{d}}$ & $40.8 \pm 1.3^{\mathrm{c}}$
\end{tabular}

Values are expressed as the mean \pm standard deviation ( $\mathrm{n}=10 \mathrm{ICR}$ mice/group). Bisacodyl, $100 \mathrm{mg} / \mathrm{kg}$ body weight; $\mathrm{LB}, 1.0 \mathrm{x} 10^{9} \mathrm{CFU} / \mathrm{kg}$ body weight; LC-Qian (L), 1x10 ${ }^{8} \mathrm{CFU} / \mathrm{kg}$ body weight; LC-Qian (H), 1.0x10 ${ }^{9} \mathrm{CFU} / \mathrm{kg}$ body weight. ${ }^{\mathrm{a}-\mathrm{f}} \mathrm{Mean}$ values with different letters over the bars are significantly different $(\mathrm{P}<0.05)$ according to Duncan's multiple range test. MTL, motilin; Gas, gastrin; ET, endothelin; SS, somatostatin; AchE, acetylcholine enzyme; SP, substance P; VIP, vasoactive intestinal peptide; LB, Lactobacillus bulgaricus; LC-Qian, Lactobacillus casei Qian; CFU, colony-forming unit.

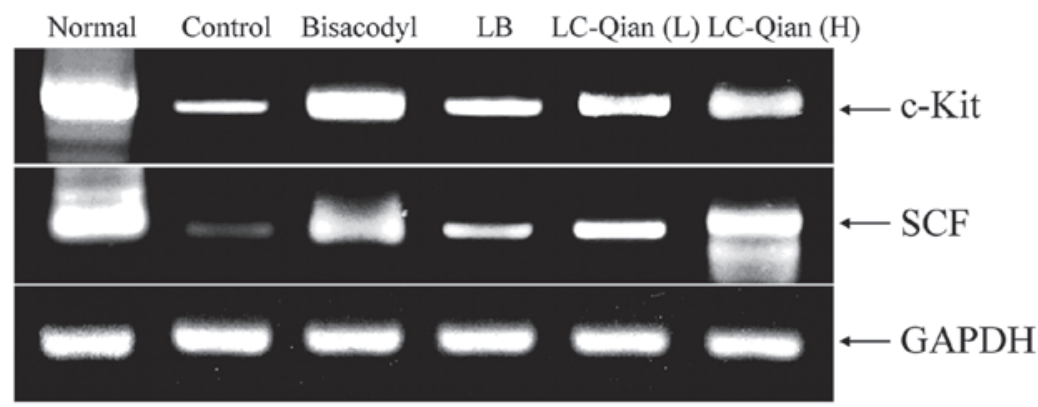

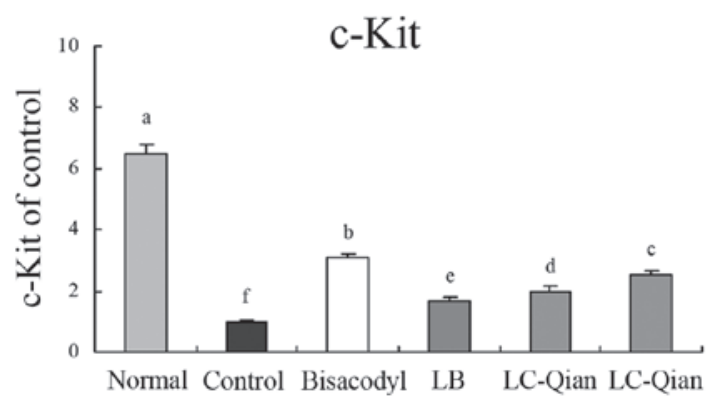

(L)

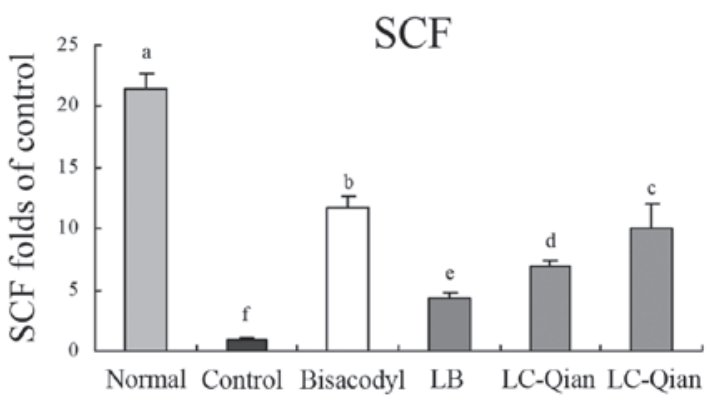

(L) (H)

Figure 5. mRNA expression levels of c-Kit and SCF in the small intestine of LC-Qian-treated mice. Bisacodyl, $100 \mathrm{mg} / \mathrm{kg}$ body weight; LB, $1.0 x 10^{9} \mathrm{CFU} / \mathrm{kg}$ body weight; LC-Qian (L), $1 \times 10^{8} \mathrm{CFU} / \mathrm{kg}$ body weight; LC-Qian (H), 1.0x $10^{9} \mathrm{CFU} / \mathrm{kg}$ body weight. Values are expressed as the mean \pm standard deviation (n=10 ICR mice/group). ${ }^{\mathrm{a}-\mathrm{f}}$ Mean values with different letters over the bars are significantly different $(\mathrm{P}<0.05)$ according to Duncan's multiple range test. LB, Lactobacillus bulgaricus; LC-Qian, Lactobacillus casei Qian. SCF, Skp, cullin, F-box containing complex; CFU, colony-forming unit.

LC-Qian normalizes gene expression levels of TRPV1, GDNF and NOS in constipated mice. The TRPV1 and NOS mRNA expression levels in the small intestine tissue of normal mice were the lowest, while GDNF expression was the highest (Fig. 6). Active carbon reduced GDNF expression and raised TRPV1 and NOS expression levels. LC-Qian was able to reduce the influence of these alterations in expression by active carbon. The mice treated with the high concentration of LC-Qian exhibited higher GDNF expression levels but lower TRPV1 and NOS expression levels than those in the LB- and low concentration of LC-Qian-treated mice $(\mathrm{P}<0.05)$.

\section{Discussion}

Functional lactic acid bacteria are used as probiotics in food and drug manufacture (15). High-quality lactic acid bacteria which withstand the highly acidic conditions in the stomach may reach the intestinal tract and colonize in the large intestine to exert beneficial effects (16). In order to determine whether 


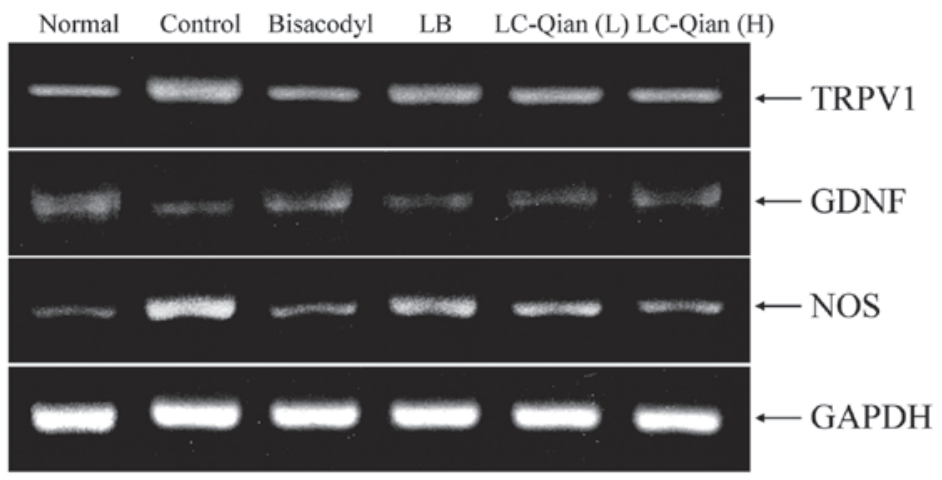

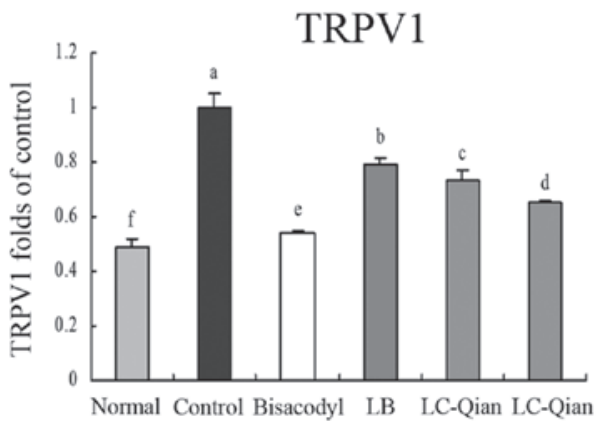

(L)

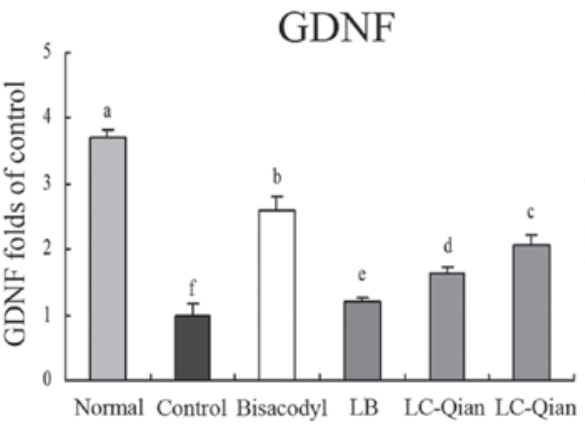

(L) $\quad(\mathrm{H})$

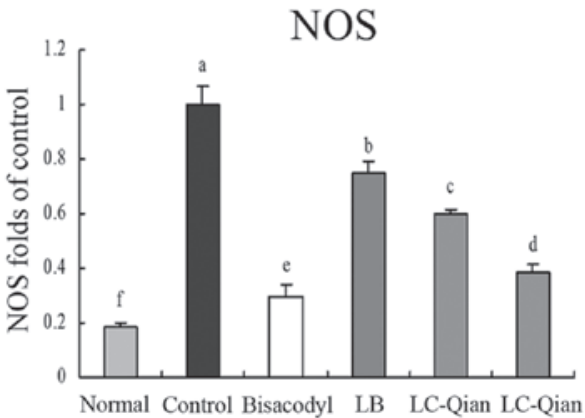

(L) $\quad(\mathrm{H})$

Figure 6. mRNA expression levels of TRPV1, GDNF and NOS in the small intestine of LC-Qian-treated mice. Bisacodyl, 100 mg/kg body weight; LB, 1.0x10 CFU/kg body weight; LC-Qian (L), $1 \times 10^{8} \mathrm{CFU} / \mathrm{kg}$ body weight; LC-Qian (H), 1.0x10 $\mathrm{CFU} / \mathrm{kg}$ body weight. Values are expressed as the mean \pm standard deviation ( $\mathrm{n}=10 \mathrm{ICR}$ mice/group) ${ }^{\mathrm{a}-\mathrm{f}}$ Mean values with different letters over the bars are significantly different $(\mathrm{P}<0.05)$ according to Duncan's multiple range test. LB, Lactobacillus bulgaricus; LC-Qian, Lactobacillus casei Qian; CFU, colony-forming unit; TRPV1, transient receptor potential cation channel subfamily V member 1; GDNF, glial cell line-derived neurotrophic factor; NOS, nitric oxide synthase.

lactic acid bacteria are able to proceed through the stomach and intestine to colonize in the large intestine, the present study used in vitro model experiments resembling conditions in the intestinal tract. In vitro experiments assessing acid resistance, cholate tolerance and hydrophobic properties were used in the present study to determine the functional effects of the probiotics. LC-Qian was observed to exhibit improved properties of acid resistance, cholate tolerance and hydrophobic properties compared with the common lactic acid bacterial strain LB, and these properties suggested that LC-Qian may be an effective probiotic.

The high cholate tolerance of lactic acid bacteria may enable them to pass through the stomach and intestine, where they may exert their functional effects (17). In addition to the effects of cholate resistance in the small intestine, lactic acid bacteria also have good hydrophobic properties for lactic acid bacterial adhesion in the mucous membrane of the small intestine (18).

The body weight is used as an index for constipation in mice. Following treatment with activated carbon in mice, body weights have been reported to reduce in line with constipation (13). Bisacodyl is a drug used in constipation therapy, and owing to its reported efficacy (19), it was used as a positive control drug in the present study. High concentrations of LC-Qian were able to reverse the changes in body weight of constipated mice to near the levels of bisacodyl-treated mice, and the body weight-preserving activity of LC-Qian was greater than that of LB.

Patients with constipation commonly exhibit abated peristalsis of the bowels $(16,17)$, and the speed of fecal movement in the gut significantly slows down, which leads to dry feces and difficulty in passing stools (13). Due to these symptoms, the frequency of defecation, amount of defecation and the moisture content of the feces are factors used to measure the level of constipation (19). Constipation results in alterations in defecation, thus, the defecation status in mice was determined in the present study. The fecal weight was used to examine the severity of constipation, as constipation reduces the amount of defecation; furthermore, fecal particle counts gave information on the level of constipation, as a reduction in fecal particles indicated that gastrointestinal movement may be affected. Finally, constipation may reduce the water content in the feces; thus, this index was also used to estimate the severity of constipation. In the present study, LC-Qian was demonstrated to improve constipation through normalizing defecation weight, counts of fecal particles and the water content of feces.

If food remains in the small intestine for a long time period, it exposes them to harmful bacteria, may make the intestinal tract prone to sickness and other viscera may be harmed by substances produced by harmful bacteria (20). Lactic acid bacteria are able to reduce the $\mathrm{pH}$ value, increasing the acid in the intestinal tract and thereby creating an environment in which harmful bacteria are unable to survive (21). Lactic acid bacteria cause alterations in intestinal tract movement and prevent the production of harmful substances (22); thus, LC-Qian may be an beneficial lactic acid bacterial strain due to its acid manufacturing capability for constipation prevention.

MTL is an important gastrointestinal hormone, which is able to increase intestinal peristalsis, promote the contraction of gastric smooth muscle and increase the speed of transit of intestinal contents through the intestinal tract (23). 
Gas is another important gastrointestinal hormone, which is able to promote gastrointestinal secretion and gastric contraction, increase the movements of the gastrointestinal tract and simultaneously promote contraction of the pyloric sphincter (24). ET is a key factor in the regulation of cardiovascular function, with a previous study reporting that maintaining the content of ET prevents acute cardiovascular diseases and controls cardiovascular diseases from worsening by constipation (25). SS is able to stimulate the secretion of gastric acid, and inhibit pepsin and gastrin release, which thus aggravates constipation (26). The release of AChE is beneficial for neural development, thus the colon intestinal pseudo-obstruction present in neuromuscular diseases is prevented, therefore reducing constipation (27). SP is an excitatory neuropeptide, which is able to stimulate bowel movements (28). Low levels of SP are associated with the dysfunction of rectal sensation, which increases rectal compliance and lead to constipation (29). VIP is a neuropeptide of neuromodulator and neurotransmitter, which may prevent the intestinal peristalsis descending (19). Lower levels of VIP have been reported to affect the content of intestinal nerves, which leads to constipation. A previous study on constipation identified that normal patients had higher serum levels of MTL, Gas, ET, AChE, SP and VIP, and lower SS serum levels than those of patients with constipation (30). These studies are in agreement with the results of the animal experiment performed in the present study.

Interstitial cells of Cajal (ICCs) are mesenchymal cells present between the intestinal nervous system and smooth muscle, and have been reported to serve important roles in the regulation of intestinal nerve signaling to smooth muscle cells (31). The ICC content in the intestines of patients with constipation has been observed to be low (32). c-Kit has been reported to increase the quantity of ICCs to relieve constipation; therefore, c-Kit was used as a marker to determine constipation. SCF was able to help to maintain ICCs, as the SCF content was proportional to ICC survival (33). A previous study demonstrated that constipation reduced the c-Kit and SCF expression levels in the colon tissue of mice (34). The present study provided similar results, as c-Kit and SCF mRNA expression levels in the constipation control mice were the lowest, and LC-Qian was able to increase these expression levels in the colon tissue of mice.

TRPV1 is a mediating factor between absorption and bowel movement. Following the activation of TRPV1, neurotransmitters are released, and these processes result in movement disorders of the small intestine. Intestinal damage causes increases in TRPV1 levels, and a clinical study showed that following injury of the intestines and movement disorder patients showed high TRPV1 levels (35). GDNF protein controls the growth and development of nerve cells, and it has further effects on the protection and restoration of injured nervous fibers. GDNF also has a functional effect on ganglion cell adjustment. Injured intestines can be repaired through increases in GDNF levels, and constipation can also be inhibited through increases in GDNF levels (36).

NOS causes endogenous NO release, is present in all gastrointestinal tissues and has an important regulatory effect on gastrointestinal movement. The discomfort resulting from colonic motility disorder in STC patients can be reduced by decreasing $\mathrm{NO}$, and constipation may be controlled by reducing the content of NOS (37). In the present study, LC-Qian showed marked effects on the control of constipation in mice as indicated by an increase in GDNF expression and a reduction in TRPV1 and NOS expression.

The present study used an animal experimental model of constipation induced by activated carbon to detect the effect of LC-Qian on constipation. The results demonstrated that LC-Qian had improved acid resistance, cholate tolerance and hydrophobic properties when compared with LB, and that the time until the first black stool defecation was decreased for the LC-Qian treated mice compared with that of the control mice. LC-Qian-treated mice exhibited an increased GI transit and the mice treated with high concentrations of LC-Qian exhibited a GI transit similar to that of bisacodyl-treated mice. LC-Qian-treated mice were observed to have higher MTL, Gas, ET, AChE, SP and VIP serum levels than those of control mice and LB-treated mice, and the SS levels exhibited opposite trends. The mRNA levels of c-Kit, SCF and GDNF in LC-Qian-treated mice were greater than those in the control mice, while TRPV1 and NOS expression levels were lower than those in the control mice. The results of the present study therefore indicated that the effect of LC-Qian is significantly higher than that of the commonly used LB probiotic. Therefore, LC-Qian is suggested as an effective potential probiotic to prevent and treat constipation.

\section{Acknowledgements}

The current study was supported by the National Science and Technology Support Program (grant no. 2012BAD13B06-5), the Natural Science Foundation of Chongqing Science \& Technology Commission (grant no. cstc2013jcyjA80006) and the Fundamental Research Funds for the Central Universities (grant no. XDJK2013B010).

\section{References}

1. Wu CS, Li J, Qian Y and Suo HY: Research progress of yak milk and fermented yak milk and their nutritional value. J Dairy Sci Technol 35: 43-46, 2012 (In Chinese).

2. Wu CS, Shu C, Li J, Qian Y and Suo HY: The research progress and prospect of yak yogurt Lactic acid bacteria. Food Ind 33: 129-133, 2012 (In Chinese).

3. Ueki A and Otsuka M: Life style risks of Parkinson's disease: Association between decreased water intake and constipation. J Neurol 251 (Suppl 7): vII18-vII23, 2004.

4. Farrugia G, Miller SM, Rich A, Liu X, Maines MD, Rae JL and Szurszewski JH: Distribution of heme oxygenase and effects of exogenous carbon monoxide in canine jejunum. Am J Physiol 274: G350-G358, 1998.

5. Wexner SD, Beck DE, Baron TH, Fanelli RD, Hyman N, et al: A consensus document on bowel preparation before colonoscopy: Prepared by a task force from the American Society of Colon and Rectal Surgeons (ASCRS), the American Society for Gastrointestinal Endoscopy (ASGE) and the Society of American Gastrointestinal and Endoscopic Surgeons (SAGES). Gastrointest Endosc 63: 894-909, 2006.

6. Farrugia G, Lei S, Lin X, Miller SM, Nath KA, Ferris CD, Levitt $\mathrm{M}$ and Szurszewski JH: A major role for carbon monoxide as an endogenous hyperpolarizing factor in the gastrointestinal tract. Proc Natl Acad Sci USA 100: 8567-8570, 2003.

7. Wang R, Sun P, Zhou Y and Zhao X: Preventive effect of Dendrobium candidum Wall. ex Lindl. on activated carboninduced constipation in mice. Exp Ther Med 9: 563-568, 2015. 
8. Battish R, Cao GY, Lynn RB, Chakder S and Rattan S: Heme oxygenase-2 distribution in anorectum: Colocalization with neuronal nitric oxide synthase. Am J Physiol Gastrointest Liver Physiol 278: G148-G155, 2000

9. Xue L, Farrugia G, Miller SM, Ferris CD, Snyder SH and Szurszewski JH: Carbon monoxide and nitric oxide as coneurotransmitters in the enteric nervous system: Evidence from genomic deletion of biosynthetic enzymes. Proc Natl Acad Sci USA 97: 1851-1855, 2000.

10. Miller SM, Reed D, Sarr MG, Farrugia G and Szurszewski JH: Haem oxygenase in enteric nervous system of human stomach and jejunum and co-localization with nitric oxide synthase Neurogastroenterol Motil 13: 121-131, 2001.

11. Xiong T, Song SH, Huang JQ, Huang Y and Xie MY: Tolerance of Lactobacillus plantarum NCU116 in stimulated digestive environments. Food Sci 32: 114-117, 2011.

12. Zhao WJ, Lv JL and Ma LY: Analysis of the surface hydrophobicity of Lactobacillus acidophilus. China Dairy Ind 39: 8-11, 2011 (In Chinese)

13. Qian Y,Zhao X and Kan J: Preventive effect of resistant starch on activated carbon-induced constipation in mice. Exp Ther Med 6 : 228-232, 2013

14. Zhao X, Kim SY and Park KY: Bamboo salt has in vitro anticancer activity in HCT-116 cells and exerts anti-metastatic effects in vivo. J Med Food 16: 9-19, 2013.

15. Arqués JL, Rodríguez E, Langa S, Landete JM and Medina M Antimicrobial activity of lactic acid bacteria in dairy products and gut: effect on pathogens. Biomed Res Int 2015: ID584183, 2015.

16. Mercenier A, Pavan S and Pot B: Probiotics as biotherapeutic agents: Present knowledge and future prospects. Curr Pharm Des 9: 175-191, 2003.

17. Saarela M, Mogensen G, Fondén R, Mättö J and Mattila-Sandholm T: Probiotic bacteria: Safety, functional and technological properties. J Biotechnol 28: 197-215, 2000.

18. Marteau P, Minekus M, Havenaar R and Huis in't Veld JH: Survival of lactic acid bacteria in a dynamic model of the stomach and small intestine: validation and the effects of bile. J Dairy Sci 80: 1031-1037, 1997.

19. Qian Y, Suo H, DU M, Zhao X, Li J, Li GJ, Song JL and Liu Z: Preventive effect of Lactobacillus fermentum Lee on activated carbon-induced constipation in mice. Exp Ther Med 9: 272-278, 2015.

20. Gibson GR and Roberfroid MB: Dietary modulation of the human colonic microbiota: Introducing the concept of prebiotics. J Nutr 125: 1401-1412, 1995.

21. Salminen S and Salminen E: Lactulose, lactic acid bacteria, intestinal microecology and mucosal protection. Scand J Gastroenterol Suppl 222: 45-48, 1997.

22. Yang F, Hou C, Zeng X and Qiao S: The use of lactic Acid bacteria as a probiotic in Swine diets. Pathogens 4: 34-45, 2015.
23. Feighner SD, Tan CP, McKee KK, Palyha OC, Hreniuk DL, Pong SS, et al: Receptor for motilin identified in the human gastrointestinal system. Science 284: 2184-2188, 1999.

24. Sjölund K, Ekman R, Akre F and Lindner P: Motilin in chronic idiopathic constipation. Scand J Gastroenterol 21: 914-918, 1986.

25. Preston DM, Adrian TE, Christofides ND, Lennard-Jones JE and Bloom SR: Positive correlation between symptoms and circulating motilin, pancreatic polypeptide and gastrin concentrations in functional bowel disorders. Gut 26: 1059-1064, 1985.

26. Soudah HC, Hasler WL and Owyang C: Effect of octreotide on intestinal motility and bacterial overgrowth in scleroderma. $\mathrm{N}$ Engl J Med 325: 1461-1467, 1991.

27. FurchgottRF and Zawadzki JV: The obligatory role of endothelial cells in the relaxation of arterial smooth muscle by acetylcholine. Nature 288: 373-376, 1980.

28. Chen FX, Yu YB, Yuan XM, Zuo XL and Li YQ: Brain-derived neurotrophic factor enhances the contraction of intestinal muscle strips induced by SP and CGRP in mice. Regul Pep 178: 86-94, 2012.

29. Tzavella K, Riepl RL, Klauser AG, Voderholzer WA, Schindlbeck NE and Müller-Lissner SA: Decreased substance $\mathrm{P}$ levels in rectal biopsies from patients with slow transit constipation. Eur J Gastroenterol Hepatol 8: 1207-1211, 1996.

30. Silkoff P, Karmeli F, Goldin E, Ewenson A, Gilon C, Chorev M, et al: Effect of substance P on rat gastrointestinal transit. Dig Dis Sci 33: 74-77, 1988.

31. Farrugia G: Interstitial cells of Cajal in health and disease. Neurogastroenterol Motil 20 (Suppl 1): 54-63, 2008.

32. Feng X, Liang X, Wang Y, He S and Cai X: Changes of the colonic physiologic functions after colonic anastomosis with a degradable stent in a porcine model. Chin Med J (Engl) 127: 3249-3253, 2014

33. Tan YY, Ji ZL, Zhao G, Jiang JR, Wang D and Wang JM: Decreased $\mathrm{SCF} / \mathrm{c}$-kit signaling pathway contributes to loss of interstitial cells of Cajal in gallstone disease. Int J Clin Exp Med 7: 4099-4106, 2014.

34. Brading AF and McCloskey KD: Mechanisms of Disease: Specialized interstitial cells of the urinary tract-an assessment of current knowledge. Nat Clin Pract Urol 2: 546-554, 2005.

35. Geppetti P and Trevisani M: Activation and sensitisation of the vanilloid receptor: Role in gastrointestinal inflammation and function. Br J Pharmacol 141: 1313-1320, 2004.

36. Xu GP, Fan YH and Lv B: Advances in understanding the role of neurotrophins in physiological and pathological processes in the intestinal tract. World J Gastroenterol 18: 2884-2888, 2010.

37. Tomita R, Igarashi S, Fujisaki S and Tanjoh K: The effects of neurotensin in the colon of patients with slow transit constipation. Hepatogastroenterology 54: 1662-1666, 2007. 